\title{
Human infection with Avian influenza A virus in Nepal: requisite for timely management and preparedness
}

\author{
Krishna Prasad Acharya ${ }^{1} \cdot$ Narayan Acharya $^{2} \cdot$ Sarita Phuyal $^{3}$. \\ Supram Hosuru Subramanya ${ }^{4}$
}

Received: 30 November 2019/ Accepted: 24 April 2020/Published online: 12 May 2020

(C) Indian Virological Society 2020

\begin{abstract}
Avian influenza virus infection in humans is an emerging zoonotic disease having high economic and public health impacts. Due to its capability for genetic reassortment, this virus can emerge as novel influenza strains with pandemic potential. Even though the first Avian influenza incidence in humans in Nepal was reported in April 2019, the threat of the disease remains unmitigated. Limited resources for surveillance, disease tracking, and weak health care facilities in low and middle-income countries will increase the possibility of the outbreak. Therefore, timely management and preparedness by strengthening veterinary and medical services, operational capabilities of laboratories, and surveillance programs through the "One-Health" approach could be crucial for the control of possible outbreaks in Nepal.
\end{abstract}

Keywords Avian influenza $\cdot$ Human $\cdot$ One health

\section{Introduction}

Approximately $66 \%$ of the population in Nepal depends on agriculture as a way of livelihood [25], and more than 70\% of the population raises livestock and poultry [1]. Since

Krishna Prasad Acharya

krishna.acharya@nepal.gov.np

1 Animal Quarantine Office (AQO), Budhanilakantha, Kathmandu, Nepal

2 The Institute of Environmental and Human Health, Texas Tech University, Lubbock, USA

3 Central Referral Veterinary Hospital, Tripureshwar, Kathmandu, Nepal

4 Manipal College of Medical Sciences, Pokhara, Nepal around $75 \%$ of the population of Nepal lives predominantly in rural areas with low socio-economic status and depends on subsistence farming [20], by no means they can get rid of direct exposure to poultry and their products. Urban Nepal, where less than $20 \%$ of the total population resides, relies on poultry meat as their primary source of animal protein. Increasing meat demand has ultimately led to intensive farming and confined animal feeding operations (CAFOs), which potentially amplify the possible public health threat of Avian Influenza (AI) [26]. Other factors, such as using poultry shed as a human shelter [12] and poor sanitation and hygiene status [5, 21], further substantiate the likelihood of AI transmission to humans. For example, recently, a 3-year-old girl in China tested positive for $\mathrm{H}_{9} \mathrm{~N}_{2}$, possibly acquired the virus from poultry as she had contact with domestic poultry before falling ill [11]. Such an incidence of acquiring Avian Influenza from poultry is much likely in Nepal. Also, there are significant concerns over the co-circulation of avian, human, and pig influenza viruses in pigs with the potential of a genetic re-assortment and emergence of a genetically proficient virus than we have yet well-thought-out [23]. Considering widespread nature of the H5N1 outbreak in Asia, the capability of influenza viruses to jump across species barriers, and close association between wild birds (asymptomatic reservoir of HPAI viral strains), domestic birds and humans, the threat of emergence of novel influenza strains with pandemic potential cannot be denied [3]. With these issues at hand, a vast majority of the Nepalese are under an imminent vulnerable situation to probable AI outbreak that could have devastating consequences. It is rational to expect worse aftermath due to limited resources for surveillance, lack of services to detect, track, report, and respond to the disease on time, and inadequate health care facilities. 


\section{Avian influenza in poultry in Nepal}

The first reported case of AI in birds in Nepal was confirmed on 16th January 2009 in the Jhapa district. Since then, several periodic outbreaks of Avian Influenza subtypes $\mathrm{H}_{5}$ and $\mathrm{H}_{9}$ have been reported in poultry $[13,17]$. The highly pathogenic avian influenza (HPAI) in birds was caused by the influenza virus of the strains $\mathrm{H}_{5} \mathrm{~N}_{1}$ of the clade 2.2 and later by 2.3.2.1a and $\mathrm{H}_{5} \mathrm{~N}_{8}$ of the clade 2.3.4.4 [10, 24], which are the same viral clades reported from South Asian countries including China and India $[10,17]$. Moreover, frequent outbreaks of HPAI of different strains in China $[9,18]$ and India $[9,10]$ further increases the threat of HPAI in Nepal. This is not just due to the long porous border, and cross border movement of birds between its neighbors but also unmanaged local markets, informal trade and uncontrolled movement of birds (wild and domestic) [24]. The repeated outbreaks of highly pathogenic Avian Influenza (HPAI) and low pathogenic Avian Influenza (LPAI) in poultry have caused substantial economic loss to the Nepalese poultry industry and severely affecting the livelihood of poultry farmers $[13,16]$. For example, from the first outbreak of 2009 to fiscal year 2016/17, a total of 237 outbreaks of HPAI have been documented, where 1,966,745 (around 2 million) poultry birds were slaughtered and compensation amount of NRs. 259,706,641 (US\$2.5 million) have been paid to farmers by the Department of Livestock Services (DLS) (Annual Technical Report. Department of Livestock Services F/Y 2016/17). Apart from this, millions of dollars of the poultry sector have been lost due to HPAI in Nepal.

\section{The global incidence of avian influenza in humans}

Avian influenza viruses do not usually infect humans. However, sporadic human infections with these viruses have been reported mainly in the Western Pacific Region like Vietnam, China, and Cambodia [10]. Globally, since 2003 a total of 861 cases of human infection with avian influenza A (H5N1) virus, predominantly of the clade 2.3.4.4, was reported from 17 countries [29] (Fig. 1), with a high case fatality rate (CFR) of approximately $52 \%$ [29].

However, in Nepal, the first human case of H5N1 was reported in April 2019, resulting in the death of a patient, which is the world's first H5N1 human infection since 2017 [6]. Other neighboring countries of Nepal, such as Pakistan [10] and Bangladesh [10] in South Asia, have also experienced episodes of AIV in humans (Table 1).

\section{Characteristics of human infection with avian influenza viruses}

Avian flu virus gets transmitted to humans via droplets or possibly dust generated from saliva, mucous, and feces of the infected birds. The person-to-person transmission was reported, and when it has been reported, it has been limited, inefficient, and not sustained [7]. However, considering the capability of frequent mutation and genetic re-assortment of avian influenza A viruses, the possibility of gaining high contagious and virulence property cannot be ruled out. Therefore, monitoring human infections and human-tohuman transmission is crucial for public health. Infection in humans has ranged from mild to severe, including conjunctivitis, influenza-like illness, sometimes accompanied by nausea, abdominal pain, diarrhea, vomiting, and severe respiratory illness. Complications include neurologic manifestations and the involvement of other organ systems. Diagnosis of human cases will usually require molecular and serological testing. CDC currently recommends a neuraminidase inhibitor (Oseltamivir, Peramivir, and Zanamivir) for the treatment of human infection [8], which are found to be $70-90 \%$ effective.

\section{SARS-CoV-2 and Avian influenza}

Currently, the world is facing severe coronavirus disease of 2019 (COVID-19) pandemic, which is caused by a genetically proficient virus, severe acute respiratory syndrome coronavirus-2 (SARS-CoV-2). Although the origin of the COVID-19 virus and its pathogenicity and immunogenicity is not known entirely, it is speculated to have been developed by genetic re-assortment between the coronavirus of bat and pangolin [30,33]. Apparently, this outbreak has no any relation with Avian Influenza as there is no resilient evidence of genetic recombination between Coronavirus and Influenza virus. However, Qinghong Zeng et al. speculated that some human coronaviruses could have acquired the hemagglutin in-esterase gene of the influenza $\mathrm{C}$ virus through a recombinant process as a result of mixed infections in human [19]. Additionally, Luytjes et al. opined a supportive view stating that recombination events as a result of the co-infection of corona virus with the influenza $\mathrm{C}$ virus might give rise to a new corona virus OC43 with acquired haemagglutinating properties [32]. The previous experiences with human influenza pandemics have demonstrated the vital role of the avian influenza virus in the origin of pandemic influenza viruses [4]. The viruses that caused the pandemics of 1918, 1957, and 1968 all had genes of avian influenza origin, which fomented the 


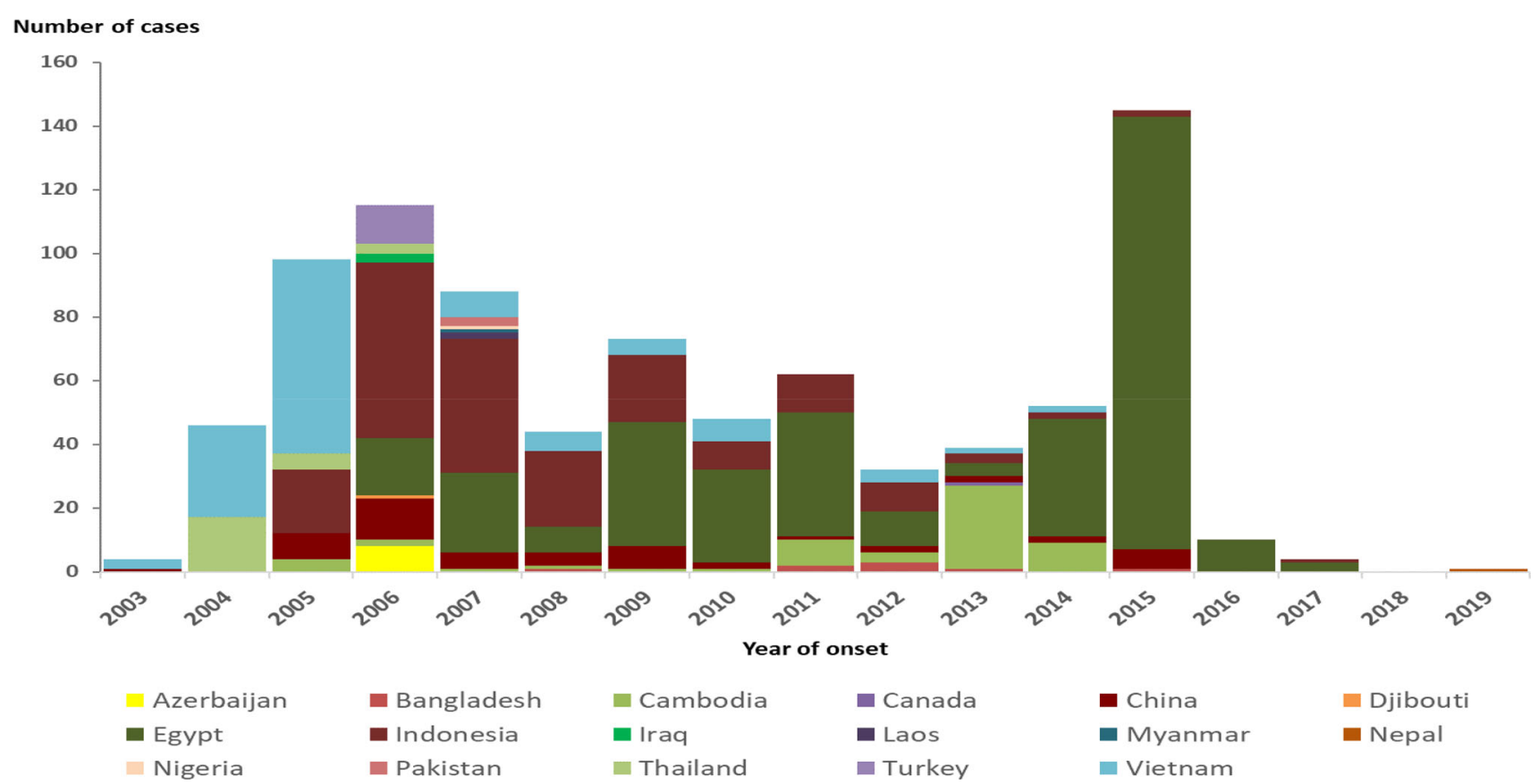

Fig. 1 Confirmed human cases of highly pathogenic Avian Influenza of the strain H5N1 by year and country during 2003-2019. (Source: The European Centre for Disease Prevention and Control-Surveillance report. Avian influenza overview November 2019-February 2020. https://www.ecdc.europa.eu/en/publications-data/avian-influenza-ov erview-november-2019-february-2020, https://doi.org/10.2903/j.efsa. 2020.6096)
Table 1 Reported human cases of the H5N1 virus in South Asia Countries

\begin{tabular}{lllllllllll}
\hline Country & \multicolumn{3}{l}{ Year of detection } & & & & Total cases reported & Total deaths \\
\cline { 2 - 7 } & 2007 & 2008 & 2011 & 2012 & 2013 & 2015 & 2019 & \\
\hline Nepal & 0 & 0 & 0 & 0 & 0 & 0 & 1 & 1 & 1 \\
Bangladesh & 0 & 1 & 2 & 3 & 1 & 1 & 0 & 8 & 1 \\
Pakistan & 3 & 0 & 0 & 0 & 0 & 0 & 0 & 3 & 1 \\
\hline
\end{tabular}

pandemic spread of such viruses [4, 27]. Recently, Wu et al. reported the first case of co-infection with SARSCoV-2 and influenza A virus in Wuhan, China [31]. Similar co-infections between AIV and SARS-CoV-2 in humans and animals might favor the emergence of novel viral strains.

\section{Preparedness and response to combat avian influenza in Nepal}

The containment of epidemics and pandemics would result in an enormous economic burden to the resource-poor countries like Nepal $[2,28]$, that is why it is better to be prepared to prevent well ahead of time. It is desirable for both cost and time-effective reasons [2, 28]. The Government of Nepal (GoN) should be vigilant on the possible outbreak of HPAI through the comprehensive risk analysis and robust surveillance system. Considering all favorable factors of AI outbreak, GoN had established a National Avian Influenza and Influenza Pandemic Preparedness and Response Plan (NAIIPPRP) 2006; Bird Flu Control Order 2008 [14], to control avian influenza in animal-health sector aiming to reduce economic loss and safeguard public health. Those plans were more focused on mass awareness through media, sensitization of high-risk areas, epidemiological investigations, outbreak control and containment measures, capacity building of concerned personnel, institutional strengthening, and inter-sectorial coordination $[14,22]$. GoN has been successful for the containment of AI outbreaks in the poultry sector by stamping out operations through culling/ killing of all infected and possibly infected poultry birds, disposal, cleaning and disinfection of infected premises, and quarantine and movement control 
in and out of infected premises [24]. Similarly, GoN has tried to halt transmission of AI virus by enforcing improved biosecurity measures in farms with intensified surveillance activities around infected zones and quarantine [24]. Moreover, attempts have been made to prevent outbreaks by risk-based surveillance systems and early detection of the virus as per the provisions made by Bird Flu Control Order 2008 (last amendment 2017) and Standard operation procedures 2011 for control and containment of Avian Influenza in Nepal [24]. Furthermore, to strengthen the AI surveillance system in Nepal, GoN has developed AI contingency and surveillance plans, which is yet to be effectively implemented.

\section{Recommendations and implementation of action plans}

At present, Nepal seems not well prepared for any imminent pandemic situation. Further, GoN has not established any surveillance and containment plan for the detection of AI in occupationally exposed groups such as poultry farmers, farmworkers, veterinarians, and veterinary technicians. It is better idea that GoN develop a comprehensive AIV surveillance in all possible hosts of influenza virus using advanced nuclear techniques [15] as soon as possible. Deeming the situation as aforementioned, an effective implementation of plans with improved inter-sectoral collaboration is direly needed. The government of Nepal is strongly suggested to focus on advancement of existing plans while strengthening veterinary and medical services, operational capabilities of laboratories, and surveillance programs in action. A robust surveillance system under the "One Health" approach could be a concrete solution for tracking circulating viruses at the human-animal interface.

Acknowledgements Authors are thankful to all the helping hands, and the anonymous reviewers for their constructive comments.

Funding No external funding was used in the preparation of this paper.

\section{Compliance with ethical standards}

Conflict of interest There are no competing interests.

\section{References}

1. Acharya A, Joshi B, DG-TS of N, 2017 undefined. Chapter V. associated biodiversity for food and agriculture in Nepal [Internet]. Pdfs.Semanticscholar.Org. Recuperat de: https://pdfs. semanticscholar.org/6718/2cb7983429955579e77ad0ac72b6c72 0b0a.pdf\#page $=77$

2. Acharya KP. Resource poor countries ought to focus on early detection and containment of novel corona virus at the point of entry. Clin Epidemiol Glob Health. 2020;0-1. Recuperat de: https://cegh.net/article/S2213-3984(20)30068-3/fulltext

3. Beerens N, Heutink R, Harders F, Bossers A, Koch G, Peeters B. Emergence and selection of a highly pathogenic avian influenza H7N3 virus. J Virol. 2020

4. Belshe RB. The origins of pandemic influenza-Lessons from the 1918 virus. N Engl J Med. 2005;353(21):2209-11.

5. Bisht KS. One Health Approach and Antimicrobial Resistance as candidates for $\mathrm{OH}$ Operationalization. Bharatpur, Chitwan, Nepal: International Poultry Symposium; (2018).

6. Centers for Disease Control and Prevention. First human infection with influenza $\mathrm{A}(\mathrm{H} 5 \mathrm{~N} 1)$ virus since sept. 2017 reported in Nepal [Internet]. 2019. Recuperat de: https://www.cdc.gov/flu/ spotlights/2018-2019/h5n1-human-infection.html

7. Centers for Disease Control and Prevention. Avian Influenza A Virus Infections in Humans I Avian Influenza (Flu). [Internet]. 2017. Recuperat de: https://www.cdc.gov/flu/avianflu/avian-inhumans.htm

8. Centers for Disease Control and Prevention. Influenza Antiviral Medications: A Summary for Clinicians. 2015;1-18. Recuperat de: https://www.cdc.gov/flu/pdf/professionals/antivirals/antiviralsummary-clinicians.pdf

9. Chatziprodromidou IP, Arvanitidou M, Guitian J, Apostolou T, Vantarakis G, Vantarakis A. Global avian influenza outbreaks 2010-2016: A systematic review of their distribution, avian species and virus subtype. Syst Rev. 2018;7(1):17.

10. Chowdhury S, Hossain ME, Ghosh PK, Ghosh S, Hossain MB, Beard C, et al. The pattern of highly pathogenic avian influenza H5N1 outbreaks in South Asia. Trop Med Infect Dis. 2019;4(4):138.

11. CIDRAP. H9N2 avian influenza case reported in Guangdong, China child - Outbreak News Today [Internet]. 2020. Recuperat de: https://www.cidrap.umn.edu/news-perspective/2020/04/newsscan-apr-08-2020

12. FAO. Poultry Sector Nepal. 2014. Recuperat de: http://www.fao. org/3/a-i3964e.pdf.

13. Gompo TR, Shah BR, Karki S, Koirala P, Maharjan M, Bhatt DD. Risk factors associated with Avian Influenza subtype H9 outbreaks on poultry farms in Kathmandu valley, Nepal. bioRxiv. $2019 ; 782375$.

14. GoN. Bird Flu Control Order 2008 (Fourth Amendment). 2017:1-19. Recuperat de: http://dls.gov.np/downloadfile/bird\% 20 flu \%20control\%20order\%202064\%20with\%204th\%20ammen dment_1552899523.pdf.

15. International Atomic Energy Agency. Using Nuclear Technologies to Fight Avian Influenza [Internet]. 2011. Recuperat de: https://www.iaea.org/newscenter/news/using-nuclear-technologie s-fight-avian-influenza

16. Karki S. Effects of highly pathogenic avian influenza H5N1 outbreak in Nepal from financial and social perspectives: a case study. Nepal Vet J. 2017;34:26-35.

17. Koirala P. Laboraotry diagnosis status of Avian Influenza Outbreak 2018. 2018.

18. Li X, Liu K, Yao HW, Sun Y, Chen WJ, Sun RX, et al. Highly pathogenic avian influenza $\mathrm{H} 5 \mathrm{~N} 1$ in Mainland China. Int $\mathbf{J}$ Environ Res Public Health. 2015;12(5):5026-45.

19. Luytjes W, Bredenbeek PJ, Noten AFH, Horzinek MC, Spaan WJM. Sequence of mouse hepatitis virus A59 mRNA 2: indications for RNA recombination between coronaviruses and influenza C virus. Virology. 1988;166:415-22.

20. Ministry of Livestock development. Livestock Statistics of Nepal Government of Nepal Ministry of Livestock Development Planning, Monitoring and Evaluation Division. 2017; Recuperat de: https://www.mold.gov.np

21. Nepal Public Health Association. Public Health in Nepal [Internet]. 2011. Recuperat de: http://www.nepha.org.np/publichealth-incicator 
22. Neupane D, Khanal V, Ghimire K, Aro AR, Leppin A. Knowledge, attitudes and practices related to avian influenza among poultry workers in Nepal: a cross sectional study. BMC Infect Dis. 2012;12(1):76.

23. Organization WH. Avian influenza-update: Implications of H5N1 infections in pigs in China [Internet]. 2005. p. 2005. Recuperat de: https://www.who.int/csr/don/2004_08_25/en/

24. Pandey KR. Current management status of highly pathogenic Avian Influenza (HPAI) in Nepal [Internet]. 2017. Recuperat de: https://www.slideshare.net/krishnaacharya167189/current-manag ement-status-of-highly-pathogenic-avian-influenza-hpai-in-nepal

25. Pradhanang U, Pradhanang S, Sthapit A, Krakauer N, Jha A, Lakhankar T. National livestock policy of Nepal: needs and opportunities. Agriculture. 2015;5(1):103-31.

26. Saenz RA, Hethcote HW, Gray GC. Confined animal feeding operations as amplifiers of influenza. Vector-Borne Zoonotic Dis. 2006;6(4):338-46.

27. Taubenberger JK, Morens DM. 1918 Influenza: the mother of all pandemics. Emerg Infect Dis. 2006;17(1):69-79.

28. UNICEF, WFP. UNICEF/WFP return on investment for emergency preparedness study. 2015;34. Recuperat de: http://www. unicef.org/publications/index_81164.html
29. World Health Organization. Cumulative number of confirmed human cases for avian influenza A (H5N1) reported to WHO, 2003-2020. 2020;1-4. Recuperat de: https://www.who.int/influ enza/human_animal_interface/2020_01_20_tableH5N1.pdf?ua=1

30. Wu F, Zhao S, Yu B, Chen Y-M, Wang W, Song Z-G, et al. A new coronavirus associated with human respiratory disease in China. Nature. 2020;579(7798):265-9.

31. Wu X, Cai Y, Huang X, Yu X, Zhao L, Wang F, et al. Coinfection with SARS-CoV-2 and influenza a virus in patient with pneumonia, China. Emerg Infect Dis. 2020

32. Zeng Q, Langereis MA, Van Vliet ALW, Huizinga EG, De Groot RJ. Structure of coronavirus hemagglutinin-esterase offers insight into corona and influenza virus evolution. In: Proceedings of National Academic Science USA. 2008

33. Zhou P, Yang X-L, Wang X-G, Hu B, Zhang L, Zhang W, et al. A pneumonia outbreak associated with a new coronavirus of probable bat origin. Nature. 2020;579(7798):270-3.

Publisher's Note Springer Nature remains neutral with regard to jurisdictional claims in published maps and institutional affiliations. 